\title{
Identify the Principles of Perawi Hadith and Journalist Ethics
}

\author{
Datuk Imam Marzuki \\ Sekolah Tinggi Agama Islam Negeri Mandailing Natal, Indonesia \\ imammarzuki.1984@gmail.com
}

\section{Abstract}

This research focus on the equality of the principles owned by perawihadist by typing a reporter is a requirement to be a journalist with integrity. Method library research, using representation theory and hermeneutics. Research results show there is similarities between principles the woman with journals while a journalist, fair, honest and open. Thus also a criterion that must be owned by a reporter according to journalist code.
Keywords

identity, principles, parawi hadith; journalist ethics

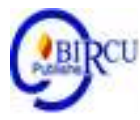

\section{Introduction}

Mass media is a tool used in conveying the message from the source to the audience by using mechanical means of communication, such as newspapers, radio, television and etc. In this case, here the mass media is print media or newspapers. (Saragih, 2018).

Reporters are people who should have the ability and ability the skills to find information and deliver it well. The success of the journalist's work is the responsibility of the community as the party he serves. As the news bearer to society, then a proclaimer must have the principles of openness and the truth must be had. The goal is to be clear and tested the truth. The province is also with writers every year hadith on zamandagi. With this background it is interesting to study in lift, remembering the function of the reporter as the contact person for the news to the end of the vacuum. Thhemadiatas interesting to be researched, because of that the amount of tellax which is available and multimedia, no other produced by reporter and reporter

As stated Bill Billov and Tom Rosenthiel, the obligation the main news is the truth (journalist's first lecture satisfaction truth) and faithfulness to women is a reporter is the community's custodian (journalist's first stage deploymentist). By assigning such things, then the work reporting must be done with a professional. As a profession, reporter must have special knowledge and special skills together with the criterion of the person perawi hadist shahih, if seen as a midst of a woman'rift is called a reality or criterion that can be being held to see something in it can be said to be a hadith Sahihata or not and the criterion is: Sanadnyati was disconnected (muttashil). His mate is fair, Perfect remembrance (dhabit), No Shadz (odd), Hadith not berillill (defective).

Preliminary diatasselnjut gave birth to the basic questions the background of this research. The question reads: "What is the equation criterion of every jihadist and writer of each journalist news medias walking with its function?". What if all journalists follow the criteria such as discussed above, certainly will not happen tell oax that much. A question it has been rallied for research and answered, because of the news activities is an activist aimed at the interests of the public. But more far from that, the media which is related also has the obligation to filter out the preachers do not make mistakes. This must be done by the medium since the beginning, that is, since the journalist is still deep first year. 


\section{Research Methods}

This research which is based on scientific research is descriptive and using library research methods. Research will be conducted by contextual articulation, which connects the old text of the components to social formations. The concept of articulation is a concept that strives representation for the purpose of togetherness.

The researcher also took the method research with the approach to hautika phenomenology of Ricoeur. This is very relevant to Islamic circles and is in line with the problem that are willing to be examined, that is classic issues, the requirements of each writer to be a jihadist, its relevance to the news reporting criteria, and the effectiveness of reporting to the people who stay here today. Next in view of Takwin, hermeneutics-phenomenology Ricoeur is a synthesis of several methods of research and methods of phenomenology.

Likewise Wilhelm Dilthe state that it was as part of it the inverse method, the primary task of quoting is how to interpret classic classifications to be owned by people living in the time, place and atmosphere of contemporary culture. By this reason, the activities of antherutics are always characteristic triadic, recognizes three related subjects meant include: the world of the text (world text), the world of theauthor (world author) and the world of the reader (world reader) who each have their own vortex points and mutual support in understand a text.

\section{Result and Discussion}

The position of a Muslim preacher is the ideal, as the continuation of the issue Nabi is regarded as an important study in the current format. This is the basic height of a view that the news of the news is an adult of the day public information. Believe it can go from it, and then it becomes information important that is absorbed by the community through media. By because it's strategic position, then has become scattered in the midst of the community through its medias. is ideally matched with norms that are valid in the profession

A reporter or reporter must have the code, which is on in essence as a guide-bag for each activist citizen journalist it is not intended to impose limitations on individual rights members of the general public in conveying entrepreneurship and information public space. Therefore, oversight of the implementation of this code of conduct it should only be done by each participant report the news and the problem completely, clearly, honestly, as well as actual, but also provide interpretation of the direction of change, transformation, based on the ideals andprofetics of Islam in harmony and be responsible for loading values.

If the withdrawal of equality is the principle of reporting with the principle of narrators, viz honesty and piety. If a Muslim's scientific ability is examined, actually have done the writing of the hadiths of the Prophet entrusted the truth is the hadith that has been narrated by people which has the nature of staying away from the prosecution of the charges. Ta'riflbn" AlwialMalikial-Hasani: "Hadiths that continue to be obtained from the narrators the fair, the dhabit, the accepted from the first year parity (the quality) not classified shadz and not pulaber-i'latlagitercelamakasemalal these are the requirements of Hadith Sahih.

Like the news function, the message should be clear, meaning news it must also be transparent, honest, sincere, and not hide anything others that are negative-like prejudice or slander crystal clear meaning and a symbol that does not have a hidden object reversed the loading of a story. The news is a report on the news that happened or actual events in the fields and mediated mass. 
Gather the factual statements that are valuable, actual, factual, important, and interesting by "filling" six elements of the news $5 \mathrm{~W}+1 \mathrm{H}$ (What / What happened, Who / Who was involved in the incident, Where / Where what happened, when / when it happened, why / why it happened, and How / How the process happens. Work must be needed human

"Strong" memory and memorization. If not then risky its coverage, results in the company being sued and lost trust of the community.

As for the more detailed criteria that were expressed by scholars above is can be explained as follows: Sanad Hade said it must to be continued. That is to say that every nurse accepts it in a way directly from the narrators who are above it, from the beginning of the baby until the last day sanad, and continue to the Nabi Muhammadsaw as part the source is called. The hadiths that are not continuous are not can be called Hadith Saheeh, yes such as Hadith Munqathi ', Mu'dhal, Mu'allaq, Mudallas and others are virtually unrelated.

The accuracy of information in communication can be seen from far away the information has been researched carefully and thoroughly, so that information presented has achieved accuracy. Convey information as soon as it is the basic principle of the religion does not because the community the problem is caused by errors information on mediasassociation can inflict a lot of harm to the communities.

The aspect of honesty or objectivity in communication is ethical which is based on the density and fact. Factuality is the key of ethics honesty. Writing and reporting is done honestly, no distorting the facts that exist. In other terms this is a tested information the truth and the person is trusted or can be recognized with integrity and its credibility. The phenomenon of investigating navigation is done as done by reporters show the number of items for the development of game journalists' investivigatif in Indonesia. Copy of course be the need for realizing the accuracy of the report (objectivity) statements that have happened Standard standards for each issuing institution.

Investigative News by Mitchell V. Charnley is an in-depth report and not a news search technique news. This confirms about the limitation of news reporters' responsibility for objectivity, not take sides and serve the public interest. According to Jalaluddin Grace, the principle with good operational operation in codeetic Sigelelta Chi, the Society of Professional Journalism, who say that the Deputy Deputy of journalististervethetruth.Untukitupara announcers must act based on intelligence, objectivity, accuracy, and fairness. It must avoid lying, distortion, slander, prejudice or intentionally to close the facts so that they give meaning warped.

There are several criteria attached to a narrator, first, the narrator is fair. Every narrator of that Hadith must is fair. What is meant by this is that you have to be married

Islam, the bighard also fulfills the following requirements:

1. Always do everything in authority and leave all the while.

2. Constantly avoiding the actions of the cigarettes; and

3. Always maintain the speech and manufacture that can tarnish muru'ah.

Likewise every reporter must look for information with wisdom and weight. Whether it should be a just concept, if that carried out the function of the function of a journalist in the plenary in accordance with the code of journalism in article 1 pointbdanc, namely: Accurate means it is believed that the situation is objective when events occur. Balanced means all parties get equal opportunities.

To get accurate news, in other news reporting practices taken along the path of confirmation, namely testing the validity of the information can be from secondary sources to primary. Through the line is already the type of possibility that the information conveyed contains lies. In Al-quranternyataadaayat that can guided the absorption of an information without more confirmation first look at the letter - Nisa 4: 83 . 


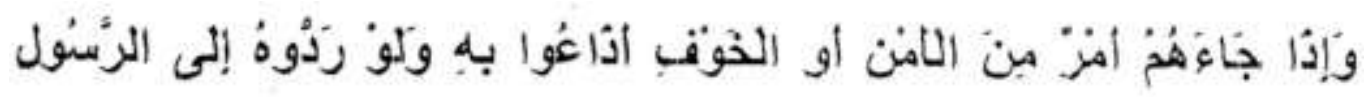

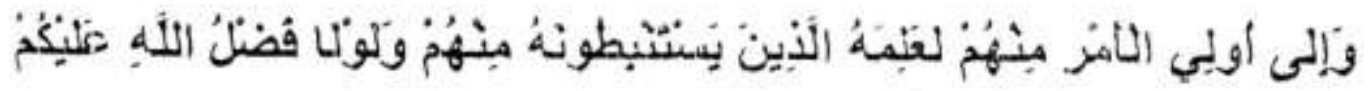

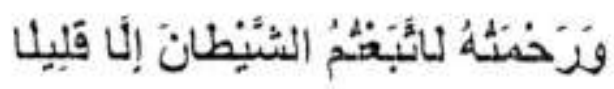

Meaning: "And when it comes to them news about security or fear, they then broadcast it. And if they surrender it to the Apostles and Ulilamridiantaramer, surely those who want to know the truth (will can) find out from them (Rasul and Ulilamri). If not because the world and the blessings of God will say to you, of course you follow shaitan, except a little (only among you)".

Furthermore, in practice the journalism includes principles and principles balanced. This means that the writing must be presented impartially. Presenting news that comes from various parties that have interests, judgments and perspectives of each of a case based on a balanced and fair principle. Be fair is the principal teachings of Islam. Said al-adildin in Islam means giving something to someone, or taking something from someone who insists on their obligations. Fair also means same balance in retaliation, such as qishash, diat and so on.Atausalam in weighing, measuring or calculating.

Fair word is the opponent opposite of dzulm not valid fair, makaiadinbbesbesifatzalim.In al-Qurankataaladwith all changes in its shape repeated 28 times among them can be found in the Christmas-aml / 6: 152.

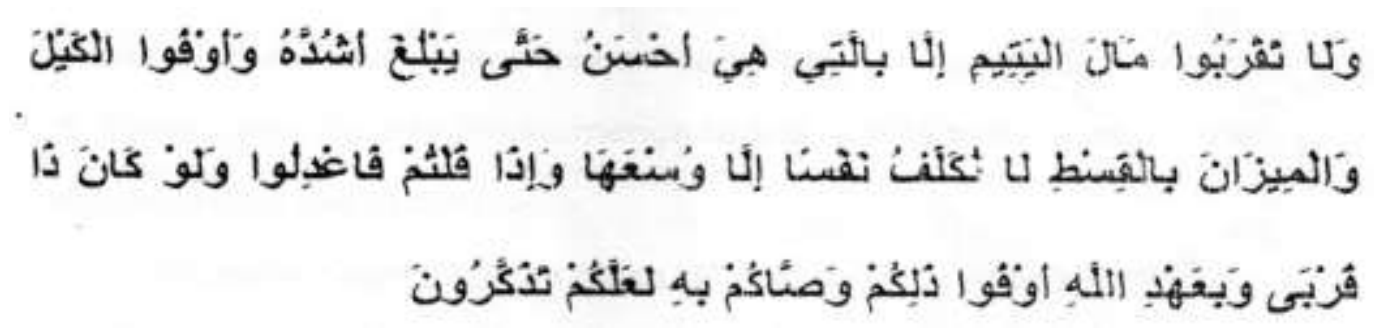

Meaning: "Please extend your training to the orphans, except by more useful ways, until he is an adult. And complete the measurements and scales fairly bear a burden on someone but rather just his ability. And when you said, if you want in effect, even if the world is a relative of you, and fulfill the promise of God.

That is what God commands you to remember ".

This discussion topic is about words with justice means that Islam is ordered to communicate with justice must communicate properly, impartially, impartially, and of course with someone's rights. In the interpretation, indeed the government says fair is more oriented towards giving testimony in court, but in general can be analogous to all form of communication, both oral and writing.

Second, the narrator is a dhobith, meaning the hadist have research in accepting girls, understand what was heard, as well as remembrance, and memorize it as if you are a girl until he narrated it the hadith that was in his notes was a mistake, or it happened exchange, subtraction and so on, which can change the hadith. Edhabith-ana narrator, thus, can be 
shared two, namely: dhobitshodran (strength of memory or memorization) and dhobitshodran (neatness and research writing or notes).

This is in line with the principle of a reporter, he must be smart his memory. The use of each event or event covered must really match all the facts that are open also by narrating it to the media, he must be thorough typed it, so that writing can be enjoyed by the general public slick and crispy. This is also in line with article 3 journalistic code of ethics reads: "Indonesian journalists always test information, preach in a balanced manner, do not mix facts and opinions judging, as well as applying the principle of presumption of guilty guilt."As for interpretation and descent of article 3 dipoint, which reads: "Testing information means doing checks and checks about the truth of that information.

To obtain data and fact determination as material information that will be conveyed to the public is needed the research is the same by people, especially news Islam accommodates when the accuracy of the information goes through several paragraph. Anyone can be tracked through the use of baby toys. In 'quranter, it can be said three times a day there is the suratalNisa '/ 4: 94, and 1 times the suratal-Hujarat / 49: 6. In Suratal - Hujarat / 49: 6, Allah says:

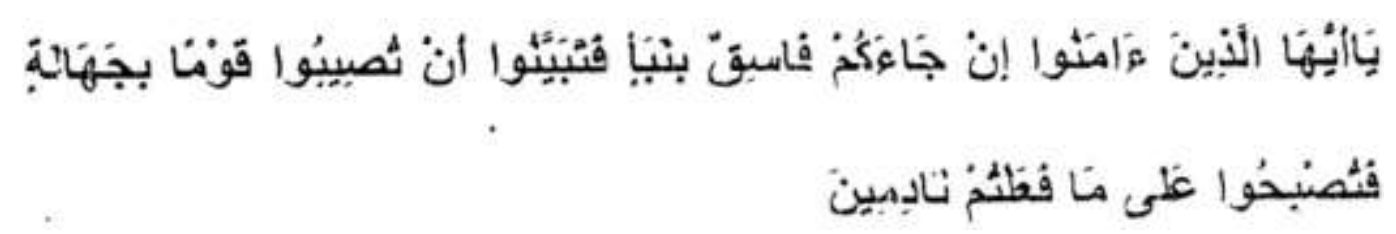

Meaning: $\mathrm{O}$ you who believe, if your eyes are not you are evil bring news, then check with your research not to inflict a disaster on a people without knowing it is what causes you to regret it what you did.

Looking at the words, the taboo is a 'demanding' room sincerity to research the clarification of information received from someone. Al-Tabariy explains the meaning of tabapayu lapaz by "be careful that you have a clear distinction information, do not rush to receive it."

Third, the hadisters mentioned didsyaz, intentsyadzatausyuzuz, plural darisyaz, it is a girl who contradicts a hadith narrated by another stronger guardian (istiqod). This understanding which is held by Shafi'idan and most other scholars such understanding can be understood as no-shahz (ghoirusyaz) is the hadiths are not contradictory with other traditions powerful or over-tsiqoh. Al-Hakim Naisabur entered the Hadith, ie the hadith which was narrated by a narrator who is thankful there are other stories that are narrated, into groups of lawyers this opinion is not held by the number of ulema scholars

The meaning for news should be based on the awareness that ethics the reporter is based on a desperate attempt to present accurate knowledge about the world of journals. It must work together organized, and need a solid team. Agapat can recognize it an obstacle to journalist policies. A reporter if have a lot of time and opportunity, of course he will find his mistake, so that he will be able to correct it the issue of reporters, they are often pressured by the time of publication. Therefore, people sometimes rely too much on principles that tomorrow can be corrected or rectified. Then a reporter it is demanded to be careful in writing a specific information regarding the charges which results in making mistakes or deviating from the rules. By knowing the indicators and the evidence that is correct support it. The evidence of perversion has been believed to have been passed, through thorough research.

The more problematic problem is that the rinse of the report is not careful, because it works individually, it ends up being biased. Reporters are always required to eliminate bias. With thus the information that was conveyed was precise the announcement of the prize cry 
as the analysis of the analysis will always be selective in receiving information before broadcasting to others. Insurataz-Zumarayat 18, Allah says:

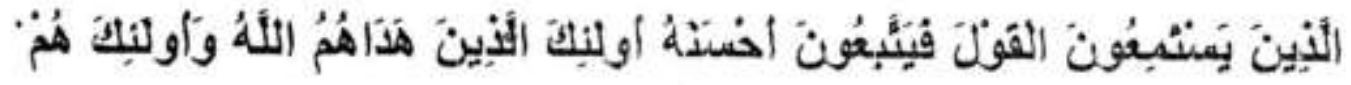

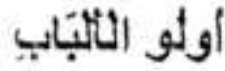

Meaning: "who listens to the words of the past follows whoever is most good among them. They are people who have been given God guidance and relate to those who have reason ".

The verse above reveals the characteristics of those referred to as ulu al-albab. The characteristics of this person are the characteristics of qal in analyzing information. Al-Istima is Al-Ishqa, the intention is to try to know something was broadcasting to the mind of something at something seriously. Trying to hear something means thinking about and analyze it in harmony with him. He distinguishes information (Al-Qawl) which is good and where is bad. That's the nature of the given The Lord is the one who is called Ul-Habib, because he is people who use film and usually are critical (Nuqqad).

Fourth, say'illat (ghoiruMua'llal), the word'illat form 'is the plural 'Illalataual'illal, according to the language means defects, disease, badness and misreading. Understanding the traditions that are true are the traditions disability or illness. Meaning that here is meaningful which is hidden or vaguely. That is, if it is seen in vain zohirhadisters mentioned Looks Shihih, but in fact it was called save disguises or doubts.

In practice, there are still journalists who ask questions to people who don't understand the problem. As a result of such a way, readers or readers don't get comprehensive and even information there is something wrong. Other people who order extra caution is found in Sura Al-Nisa / 4: 94, but it is intended more for be careful in accusing someone, whatever in a situation of war.

In addition to researching information received, reporter ethics hinting to examine the integrity and credibility of the source of given information.People in accordance with the confirmation in the above paragraph, actually, it can't be turned into a source because it has bad practices in the Islamic faith. Trust in the source is a prerequisite in reporter ethics. In the Qur'an also stressed, if there is a problem he requires correct answers, and then ask questions to the hero. God remembers in Q.S.An-Nahl / 16: 43: Meaning: "And not to send before you, except for the men we live in they, then ask the people who have knowledge if you don't know "

That means if the reporter wants an information format let think of more than first what you are the source of taking into account his scientific discipline and capacity as source of information. How to do the flicker seen in the beginning of verse 7 after the Hujarat / 49:

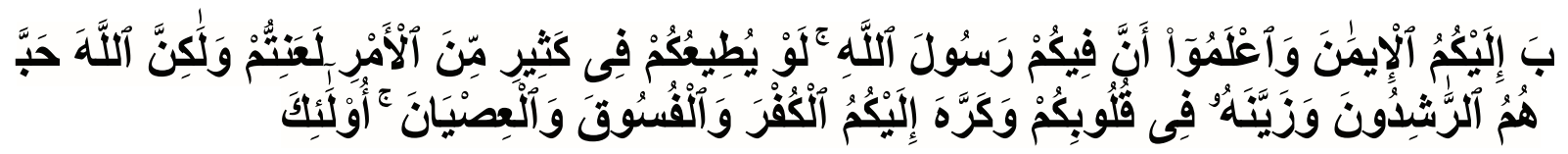

Meaning: And know that among you there is the Messenger of Allah. If your obedience (willingness) in some department is true, you will have trouble but God makes it. We love God and make it beautiful in the world the heart must be made into a disbelief, frustrated and procedural procedures. They are the people who follow straight. 


\section{Conclusion}

Research results show there are similarities between the principles the woman with journals while a journalist. fair, honest and open. Thus also a criterion that must be owned by a reporter according to journalist coding.

\section{References}

Abu Ja;far Muhammadbin JarirAl-tabari,Jami;al-Bayan (1968). Mesir: Musthafa albabal Halabi

Abd Al.HilalAl-Askary. (1973) Al-Faruqfilal-Luqhat, Beirut: Dar Al Afaq Al-Jadidat.

Abi Al-Su'ud. (1980). TafsirAl-allamatabiAl-Su'ud,Libanon: DarAl-fikr

Edi Mulyono,et al. (2012).BelajarHermeneutika :Dari Konfigurasi Filosofis Menuju Praktis Islamic Studies.Jogjakarta:IRCiSoD.

Jalaluddin Rakhmat. (1996). "EtikaKomunikasi: Perspektif Religi”,Makalah Seminar PerpustakaanNasional,Jakarta

Muhammad‘Alwial-Malikial-Hasani,al-Minhalal-Lathifufi Ushulial-Hadis Tahrif, taba'biTasrihWizarahal-A'lam,1410H.

Munzier Suparta dan Utang Ranu wijaya. (1993). IlmuHadis, Jakarta: PT. Raja Grafindo Persada

M.M.Azami. (1994). HadisNabawidanSejarahKodifikasinya, Jakarta: Pustaka Firdaus.

NawirYuslem, Ulumul Hadis. (1997). Jakarta: PT Mutiara Sumber Widya.

Radianti dan Estin Sriyani. (2020). Muslim, Bandung: Mizan.

Rahmaida. (2006). Metode Penelitian Studi Media dan Kajian Budaya,Jakarta: Prenada MediaGroup,2016.

Saragih, M.,Y. (2018). Some Characteristics of Islamic Journalism Based on Al Quran. Budapest International Research and Critics Institute-Journal (BIRCI-Journal). P. 01-10

Septiawan Santana H. (2004). Pewarta meInvestigasi, Jakarta: Yayasan Obor Indonesia, Rethingking Traditionin Modern Islamic Thought, diterjemahkanoleh: Jaziar

Takwin, Bagus, Juneman. 2011. Kesadaran perubahan Diri Dan ersepsi Terhadap Perubahan Sosial

William L. Riversdan Cleve Mathhews. (1994). Ethnic, for the Media, terjemahan Arwah Setiawan, Jakarta: Gramedia. 